\title{
DIVERSITY MANAGEMENT CONCEPT FROM THE PERSPECTIVE OF CRitical Management STUDIES PARADIGM (CMS) IN MANAGEMENT SCIENCE
}

\author{
KONCEPCJA ZARZĄDZANIA RÓŻNORODNOŚCIĄ \\ Z PERSPEKTYWY PARADYGMATU (NURTU) \\ KRYTYCZNEGO W NAUKACH O ZARZĄDZANIU
}

\begin{abstract}
The purpose of this article is to attempt a critical analysis of the concept of diversity management. Attention was drawn to the essence and impact of humanization of management on the development of the concept of diversity management. The research method adopted in the article is a critical analysis of the literature and inference.

The article analyzes the concept of diversity management from the perspective of a critical paradigm (CMS) in management sciences. Selected aspects of management sciences from the perspective of their impact on the concept of diversity management were presented. As a result of the conducted analyzes, the need to formulate new paradigms in management in the conditions of using various human resources was found. The interdisciplinary aspect of the concept of diversity management is emphasized, which is manifested by the existence of connections with other sciences in management sciences (economics, law or psychology).
\end{abstract}

\section{STRESZCZENIE}

Celem niniejszego artykułu jest próba krytycznej analizy koncepcji zarządzania różnorodnością. Zwrócono uwagę na istotę oraz wpływ humanizacji zarządzania na rozwój koncepcji zarządzania różnorodnością. Metoda badawcza przyjęta w artykule to krytyczna analiza piśmiennictwa i wnioskowanie. Dokonano w nim analizy koncepcji zarządzania różnorodnością z perspektywy paradygmatu krytycznego (CMS) w naukach o zarządzaniu. Przedstawiono wybrane aspekty nauk 
o zarządzaniu z perspektywy ich wpływu na koncepcję zarządzania różnorodnością. W wyniku przeprowadzonych analiz stwierdzono potrzebę formułowania nowych paradygmatów w zarządzaniu w warunkach wykorzystania różnorodnych zasobów ludzkich. Podkreślono aspekt interdyscyplinarności koncepcji zarządzania różnorodnością, która przejawia się występowaniem powiązań z innymi naukami w naukach o zarządzaniu (ekonomią, prawem czy psychologią).

KEYWORDS: diversity management, Critical Management Studies paradigm, management science, diverse human resources

SŁOWA KLUCzOWE: $z$ arządzanie różnorodnościa, paradygmat krytyczny, nauki o zarządzaniu, zróżnicowane zasoby ludzkie

\section{WPROWADZENIE}

Można powiedzieć, iż krytyczne refleksje w naukach o zarządzaniu, w tym dotyczące procesów organizacji i zarządzania, pojawiały się od początku istnienia tych nauk. Szkoła humanizacyjna, która zasadniczo spowodowała głęboką rewolucję poglądów, wyrażającą się właśnie w odkryciu czynnika ludzkiego, zwana nurtem human relations, czyli stosunków międzyludzkich, z jej głównymi przedstawicielami na czele (Elton Mayo, Douglas McGregor, Hugo Münsterberger, Fritz Jules Roethlisberger, Abraham Harold Maslow, Frederik Herzberg) to przykład krytyki ówczesnych teorii i instrumentalnego sposobu kierowania ludźmi (Maslow, 1934, s. 370-396; McGregor, 1960; Münsterberger, 1913; Roethlisberger \& Dickson, 1939). Badania prowadzone przez Eltona Mayo (Koźmiński, Piotrowski, 2010) w zakładzie Hawthorne w Chicago w latach 1924-1932 zaczęły poddawać w wątpliwość ówczesne teorie. Badacz ten stwierdził, że warunki pracy, czynniki społeczne oraz dynamika grupy również są ważnymi czynnikami wpływającymi na zachowanie pracownika. Pokazał złożoność procesu motywacji. Zasadniczo wspomniani powyżej badacze akcentowali rolę kontekstu społecznego (wpływu grupy i kultury) oraz indywidualnych potrzeb człowieka i w swoich rozważaniach koncentrowali uwagę na niskiej wydajności indywidualnej, konfliktach, nadmiernej absencji w pracy, nadmiernej płynności kadr czy wzroście niezadowolenia wśród pracowników, krytykując teorie głównego nurtu nauki o zarządzaniu. 


\section{NURT KRYTYCZNY - ASPEKTY TEORETYCZNE}

Zaczątek dla rozwoju nurtu krytycznego stanowiły poszukiwania alternatywnych podejść związanych z nurtami: postmodernistycznym, radykalnego strukturalizmu, interpretatywno-symbolicznym oraz narracyjnym (Kostera, 1996). Nurt krytyczny w zarządzaniu (Critical Management Studies - CMS) jest stosunkowo nową perspektywą, która wykrystalizowała się dopiero na początku lat 90. XX w. Za początek instytucjonalnego rozwoju tego nurtu uznawany jest rok 1992, w którym opublikowana została praca Matsa Alvessona i Hught Wilmotta (1992). Pionierskie prace podejmujące wątek demistyfikacji ideologicznych i opartych na strukturach dominacji funkcji zarządzania pojawiły się jeszcze w latach 70. XX w. (Braverman, 1974), jednak w ostatnich dwóch dekadach nurt krytyczny zarządzania przybrał postać zinstytucjonalizowanego dyskursu za sprawą wielu publikacji, badań, konferencji, czasopism środowiskowych oraz działalności stowarzyszeń (np. sekcja CMS amerykańskiej Academy of Management) (Sułkowski, 2012, s. 163).

Obszarem krytyki CMS jest dominujący nurt nauki i praktyki zarządzania, który może być określony jako postmodernizm czy nurt interpretatywno-symboliczny (Johnson \& Duberley, 2003). Takie ujęcie nurtu krytycznego nie jest doskonałe, jednak może być uznawane za pewien sposób uprawiania dyskursu organizacyjnego. Podstawę wyodrębnienia paradygmatu krytycznego w zarządzaniu może stanowić macierz paradygmatów zaproponowana przez Gibsona Burrella i Garetha Morgana, zmodyfikowana przez Łukasza Sułkowskiego (2014, s. 37) (tabela 1).

Tabela 1.

Paradygmaty nauk społecznych wg Gibsona Burella i Garetha Morgana

\begin{tabular}{|c|c|c|c|}
\hline \multirow{2}{*}{$\begin{array}{c}\text { Założenia } \\
\text { poznawcze } \\
\text { - ideał nauki }\end{array}$} & Obiektywizm & $\begin{array}{c}\text { Funkcjonalizm (paradygmat } \\
\text { neopozytywistyczno-funkc- } \\
\text { jonalistyczno-systemowy) }\end{array}$ & $\begin{array}{c}\text { Radykalny strukturalizm } \\
\text { (nurt krytyczny } \\
\text { zarządzania) }\end{array}$ \\
\cline { 2 - 4 } & Subiektywizm & $\begin{array}{c}\text { Paradygmat interpretatywno- } \\
\text {-symboliczny }\end{array}$ & $\begin{array}{c}\text { Radykalny humanizm } \\
\text { (postmodernizm) }\end{array}$ \\
\hline
\end{tabular}

Źródło: G. Burell, G. Morgan. (1976). Sociological Paradigms and Organizational Analysis, London: Heinemann; Ł. Sułkowski. (2012). Epistemologia i metodologia zarządzania, Warszawa: PWE, za: Ł. Sułkowski. (2014). Paradygmaty krytyczny organizacji i zarzadzania. W: Ł. Sulkowski, M. Zawadzki (red.), Krytyczny nurt zarządzania, Warszawa: Difin, s. 37. 
Macierz paradygmatów zaproponowana przez Gibsona Burella i Garetha Morgana (1976) nie zawierała nurtu krytycznego zarządzania, gdyż wówczas nie doszło jeszcze do wyodrębnienia tego podejścia. Właśnie wg Sułkowskiego można przyjąć, że zaproponowany przez wspomnianych wyżej badaczy „radykalny strukturalizm” trafnie oddaje z jednej strony istotę pogłębionej krytyki dyskursu zarządzania opartej na rozpoznaniu nierównej i niesprawiedliwej struktury społecznej, zaś z drugiej postulat aktywizmu, a więc emancypacyjnej zmiany prowadzącej do zmiany spetryfikowanego ładu. Zasadniczo nurt krytyczny opiera się na założeniu istnienia obiektywnej rzeczywistości społecznej, która wymaga jednak fundamentalnej przebudowy. Prawdy społeczne są ukryte we wszechobecnych mikro- i makrostrukturach władzy. Natomiast rola nauk społecznych polega na odkrywaniu zakamuflowanych mechanizmów władzy, dominacji i nierówności społecznej, a także na dokonywaniu zmian świadomości i rzeczywistości społecznej.

Nurt krytyczny zarządzania proponuje alternatywne w stosunku do dominującego nurtu zarządzania spojrzenie na obszary dyskursu, jak: teoria organizacji i metodologia, kultura w zarządzaniu, zarządzanie zmianą, zarządzanie zasobami ludzkimi i wiele innych. Swoistość krytycznego spojrzenia na zarządzanie można dostrzec w szczególności poprzez konfrontację z innymi paradygmatami (Sułkowski, 2014, s. 37-38).

\section{Podstawowe OBSZARY TEORETYCZNE ZARZĄDZANIA RÓŻNORODNOŚCIĄ}

Rozważania dotyczące zarządzania różnorodnością należy rozpocząć od próby określenia istoty tego pojęcia, w tym terminu różnorodności. Pojęcie różnorodności odnosi się do różnic wszelkiego rodzaju i wywodzi się od terminu „bioróżnorodność”. Badaczka Deborah Litvin (1997, s. 187-209; 2006, s. 75-94) badała korzenie różnorodności i doszła do wniosku, że termin ten został najwyraźniej zapożyczony z nauk biologicznych i włączony do nauk o zarządzaniu, bez szczególnego uwzględnienia jego przeddarwinowskich powiązań.

Amerykańskie badaczki Marilin Loden i Judy Rosener (1991) zdefiniowały podstawowe kategorie, w obrębie których ludzie się różnią, rozpatrywane $\mathrm{z}$ perspektywy dwóch płaszczyzn - to tradycyjne i najprostsze ujęcie 
- do których zalicza się: wymiar pierwotny różnorodności, zwany również wtórnym czy analogicznie wymiar poziomy i pionowy. Przyjmuje się, że istnieje sześć podstawowych wymiarów pierwotnych różnorodności, tj.: wiek, pochodzenie etniczne, płeć, (nie)pełnosprawność, „rasa” i orientacja seksualna. Natomiast wtórne wymiary różnorodności bywają mniej widoczne lub w ogóle niewidoczne, mogą mieć mniejsze znaczenie w życiu człowieka i można je zmienić. Należą do nich: wykształcenie, język, wygląd fizyczny, stan cywilny, styl życia, system wartości, spojrzenie na świat, nastawienie, etyka i aspekty psychospołeczne itd. (Griggs, 1995, s. 1-14; Thomas, 2002, s. 1-33; Car-Ruffino, 1993; Triandis, 2002, s. 133-153).

Literatura przedmiotu poświęca uwagę zdefiniowaniu pojęcia różnorodności z perspektywy zarządzania nią w organizacji. W jednym z pierwszych artykułów o różnorodności została ona opisana jako „ludzie z różnych środowisk etnicznych, różnej narodowości, wieku, religii i klasy społecznej” (Carter, Kepner, Shaw, Woodson, 1982, s. 49-53). Z biegiem lat różnorodność odnosiła się praktycznie do wszystkich cech, również tych nowo dodanych, takich jak płeć, klasa ekonomiczna, stan cywilny, wykształcenie, niepełnosprawność, doświadczenie zawodowe itp.

Natomiast amerykański badacz Caleb Rosado (1997, s. 3-15) poprzez „różnorodność” rozumie wszystkie różnice wnoszone przez ludzi do organizacji lub grupy. Ta szeroka definicja umieszcza zagadnienia dotyczące różnorodności poza podejściem „my kontra oni” (dana tożsamość społeczna vs inna tożsamość społeczna), aby skoncentrować się na wykorzystywaniu i maksymalizacji różnorodności dla osiągnięcia celów indywidualnych czy organizacyjnych (Waszczak, 2009). Alison M. Konrad, Pushkala Prasad, Judith K. Pringle (2006) wskazują, że u podstawy różnorodności leży to, iż dotyczy ona zagadnień różnic i włączania, zaś efektem tej różnorodności w organizacji jest cenny zróżnicowany zespół przyczyniający się m.in. do powstawania różnorodnych doświadczeń, różnych punktów widzenia sprzyjających współpracy, do twórczego rozwiązywania problemów, innowacyjności oraz kreatywności.

Kontynuując i przechodząc do definicji zarządzania różnorodnością, należy zauważyć, że jest ich wiele, są szerokie i złożone, dlatego trudno ustalić jeden standard lub system obejmujący wszystkie aspekty tej problematyki. W licznych publikacjach w różnorodny sposób definiuje się samą kategorię 
oraz jej elementy składowe. Przykładowo badacze Mustafa Özbilgin i Ahu Tatli (2008, s. 8) proponują nowoczesne, globalne podejście do zarządzania różnorodnością. W opinii autorów globalne zarządzanie różnorodnością to: „planowanie, koordynowanie i wdrażanie zestawu strategii, taktyk, i inicjatyw oraz programów szkoleniowych i jednostkowych doświadczeń i pochodzenia pracowników, a także ich zainteresowań, przekonań, wartości i podejść do pracy w organizacji o międzynarodowych, wielonarodowych, globalnych, transnarodowych potencjałach pracowniczych i działalności" (Özbilgin \& Tatli, 2008, s. 8). Ci sami autorzy kilka lat później definiują zarządzanie różnorodnością jako filozofię zarządzania polegającą na uznawaniu i docenianiu różnorodności w organizacjach, mającą na celu poprawę wydajności organizacji (Özbilgin \& Tatli, 2011, s. 1229-1253). Autorzy zasugerowali, że takie podejście przedstawiono jako alternatywę dla polityki równych szans. Według nich jest ono odzwierciedleniem trendu liberalizacyjnego i deregulacyjnego w USA i Wielkiej Brytanii. Istotne jest rozróżnienie, że o ile równe szanse mogą odnosić się do szans lub autonomii, do procesu i/lub rezultatu, o tyle zarządzanie różnorodnością przeważnie odnosi się do cech grup i osób (pracowników, konsumentów lub innych).

Zasadniczo zarządzanie różnorodnością należy definiować w jak najszerszy sposób, rozumiejąc je jako systematyczne działania organizacji zmierzające do zaangażowania różnorodności zasobów ludzkich w działalność firmy i traktując różnorodność jako przewagę strategiczną. Przegląd definicji pozwala również zauważyć, że zarządzanie różnorodnością to kategoria interdyscyplinarna wykorzystująca spojrzenie zarówno z punktu widzenia nauk ekonomicznych, społecznych, jak i przyrodniczych. Ale też to koncepcja, która rozwinęła się na podstawach historycznych i teoretycznych i ma silne korzenie w praktyce.

\section{PARAdYgMAT KRYTYCZNY ZARZĄDZANiA RÓŻNORODNOŚCIĄ}

Krytyczna refleksja dotycząca koncepcji, metod oraz procesów zarządzania różnorodnością rozpowszechniła się pod koniec XX w., a jej rezultaty w znacznym stopniu przyczyniły się do dalszego jej rozwoju. Należy wspomnieć, że paradygmat krytyczny CMS jest opozycyjny do dominującego 
w naukach o zarządzaniu podejścia neopozytywistycznego i funkcjonalistycznego (Sułkowski, 2014). Nie ulega wątpliwości, że nurt krytyczny zarządzania różnorodnością proponuje spojrzenie na tę koncepcję nie tylko przez pryzmat efektywności ekonomicznej (aspekt biznesowy).

Przedstawiciele nurtu krytycznego Alison M. Konrad, Pushkala Prasad i Judith Pringle (1997, s. 4-8) wskazywali, że różnorodność była hołubiona za pomocą sugestywnych metafor, takich jak ,tygiel”, „patchworkowa narzuta”, „wielokulturowa/kulturowa mozaika/tęcza”. Niemniej jednak wspomniani autorzy pisali, że „tygiel może stać się kotłem, narzuta może się podrzeć, na mozaice mogą pojawić się pęknięcia, a tęczę można zniekształcić”. Ubolewali, że znaczna część literatury przedmiotu na temat zarządzania różnorodnością ma tendencje do pomijania tych dylematów. Badacze ci również podkreślali siłę warsztatów i szkoleń w osiąganiu celów na rzecz różnorodności w miejscu pracy, jednocześnie wskazując na łatwe ryzyko przekształcenia jej na skutek tej działalności w miejsce systematycznego i problemowego tworzenia inności. Przykładowo zwracali uwagę, że o ile eliminowanie zjawiska „szklanego sufitu” i innych przeszkód jest zalecane przez praktyków, to już możliwość różnorodności wśród kierownictwa nie jest zazwyczaj omawiana, a nawet sugerowana wewnątrz organizacji (Konrad, Prasad i Jringle, 1997, s. 4-8).

Brytyjskie badaczki Penny Dick i Catherine Cassell (2002) argumentują, że cała dziedzina zarządzania różnorodnością ma niewystarczające podstawy teoretyczne i charakteryzuje się partyzanckim podejściem i uniwersalistycznymi ramami, które sprawiają, że odpowiednie zrozumienie nierówności i dyskryminacji w miejscu pracy staje się problematyczne. Według badaczek jedną z kluczowych spraw, która została znacząco zaniedbana w literaturze przedmiotu, jest kwestia oporu wobec inicjatyw dotyczących zarządzania różnorodnością. Wynika to przede wszystkim z faktu, że koncepcja zarządzania różnorodnością promowana jest jako podejście leżące w interesie wszystkich grup, niezależnie od różnic pomiędzy nimi - argument mający swoje korzenie w dyskursie biznesowym dotyczącym tej problematyki.

W teorii głównego nurtu krytyce podlegają również założenia esencjalistyczne dla tej koncepcji. Deborah Litvin (1997, s. 187-209) zauważa, że przy swoim podejściu do różnorodności, dyskurs dotyczący zarządzania bezrefleksyjnie włącza esencjalistyczne założenia z dziedziny nauk przyrodniczych. 
Badaczka również krytykuje fakt, że społecznie konstruowane kategorie (grupy) społeczne są portretowane jako oczywiste, naturalne i niezmienne, a zatem wykluczają jakiekolwiek rozważanie mechanizmów zmiany. Podobne zaniepokojenie wyrażają badacze Anna Lorbiecki i Gavin Jack (2000, s. 17-31), wskazując, że różnorodność jest przedstawiana jako dotycząca stałych różnic, co sugeruje, że nie jest możliwy ruch ani w obrębie, ani poprzez widoczne lub niewidoczne granice. Badacze ci również zidentyfikowali kwestie krytyczne odnoszące się do znaczenia zarządzania różnorodnością w organizacji i podejścia do tej różnorodności. Po pierwsze, wskazano, że kierownictwo czy osoby zarządzające są przedstawiani jako uprzywilejowany obszar (grupa), argumentując, że różnorodność to obszar do zarządzania. Takie podejście wskazuje na funkcjonowanie dwóch grup: zarządzających oraz zasobów ludzkich, które są różnorodne (pracownicy). Po drugie, nakreślanie granicy wokół „zarządzanej różnorodnej grupy" umożliwia zidentyfikowanie i kontrolowanie różnorodności, gdyż mieści się ona w jednej przestrzeni („odmiennej” grupie). Po trzecie, maskowanie różnorodności zarządzających często stanowi mechanizm kontrolny, pomaga znieść wszelkie podlegające kwestionowaniu różnice ludzkie w obrębie grupy. Ponadto Philomena Essed wskazuje, że wyraźna chęć „włączenia” osób postrzeganych jako odmienne maskuje leżące u podstaw próby kulturowego „klonowania”, tj. próby przyjęcia zasady „więcej takich samych”.

Innym aspektem podnoszonym przez krytyków zarządzania różnorodnością jest kwestia faworyzowania kontekstu biznesowego. Zasadniczo uznaje się, że koniec XX w. to początek rozwoju koncepcji zarządzania różnorodnością i moment, kiedy zarządzanie różnorodnością staje się zagadnieniem o charakterze naukowym i praktycznym, zarówno w USA, jak i w Europie Zachodniej. Za rozwój świadomości dotyczącej istotności różnorodności $\mathrm{w}$ miejscu pracy w latach 90. w USA odpowiadał raport zatytułowany Workforce 2000: Work and workers for the 21st century. W latach 90. XX w. retoryka różnorodności przemieściła się w kierunku ujęcia business case, sprawiając, iż koncepcja ta była postrzegana jako podejście wspierające różnorodność pracowników organizacji. W latach 90. w USA wiele firm wprowadziło w życie inicjatywy dotyczące różnorodności m.in. za sprawą wcześniej wspomnianego raportu Workforce 2000..., który znacząco nasilił zainteresowanie efektywnym wykorzystaniem coraz bardziej zróżnicowanych zasobów ludzkich. 
Wcześniej wspomniani badacze Anna Lorbiecki i Gavin Jack (2000, s. 17-31) twierdzą, że przekształcenie zarządzania różnorodnością w problem ekonomiczny legitymizowało organizacyjną analizę reakcji pracowników na różnorodność i zasugerowało, że są sposoby zmieniania ich, jeżeli reakcje te zostaną uznane za niewłaściwe. W świetle tak przyjętego dyskursu zarządzanie różnorodnością stało się programowalne, i można je włączać do metod i procedur zarządzania zasobami ludzkimi. Zaś Deborah Litvin (2006, s. 85-86) podaje, że zgodnie $\mathrm{z}$ przyjętym podejściem biznesowym to ludzie $\mathrm{w}$ organizacji są środkiem, a końcową wartością jest osiąganie celów organizacji. Wynika to z faktu, że dyskurs zagadnienia biznesowego wywodzi swoją pozycję z ekonomicznego megadyskursu, który „stawia na osiąganie celów ekonomicznych jako ostatecznej zasady przewodniej i narzędzia wyjaśniającego dla ludzi w organizacji”.

Kwestią równie często podnoszoną przez krytycznych badaczy jest pomijanie w głównym nurcie zagadnienia siły (Foldy, 2002, s. 92-112; Konrad, Prasad i Pringle, 2006, s. 1-22; Heran, Collinson, 2006, s. 299-322; Wrench, 2005). Na przykład Erica Gabrielle Foldy (2002, s. 92-112) wskazuje, że w dyskusjach nad różnorodnością i tożsamością w organizacjach często brakuje wymiaru siły. Badaczka twierdzi, że zarządzanie różnorodnością oznacza zarządzanie tożsamością. Zauważa, że poprzez zwracanie uwagi na różnorodne cechy swoich pracowników pracodawcy są w sposób nieunikniony zaangażowani w kształtowanie tego, w jaki sposób definiują oni i postrzegają siebie. Erica Gabrielle Foldy (2002, s. 109) uważa, że należy zająć się przede wszystkim zagadnieniami siły i dominacji, ponieważ „programy dotyczące różnorodności, które bagatelizują lub ignorują sprawy dominacji i podległości nie mogą odnieść sukcesu przy wprowadzaniu nawet powierzchownych zmian w organizacji: „omijają słonia w pokoju «”. Badaczka ta argumentuje, że z perspektywy Michaela Foucaulta - francuskiego filozofa i historyka - dyskurs zagadnienia biznesowego jest jednym z mechanizmów, za pomocą którego programy dotyczące różnorodności po prostu powielają relacje siły. Wskazuje, że dzięki wykorzystaniu korzyści biznesowych (wzrost rentowności, efektywności, wydajności) jako uzasadnienia dla podejmowania realizacji takich programów przedsiębiorstwa mogą ignorować inne imperatywy, jak dążenie do sprawiedliwości czy utrzymujące się problemy dyskryminacji i dominacji (Foldy, 2002, s. 104). 
W krytycznym nurcie literatury na temat zarządzania różnorodnością znajdujemy również stanowisko badaczy Margaret Stockdale i Faye Crosby (2004, s. 32-44), którzy wskazują, że:

1. Różnorodność upośledza organizacyjna efektywność.

2. Przedstawiciele grup defaworyzowanych na rynku pracy, np. kobiety, nie wykazują zaangażowania, żeby być zatrudniani.

3. Niepełnosprawność podnosi koszty zatrudnienia.

4. Starsi pracownicy generują dodatkowe koszty w organizacji i nie dają możliwości zwrotu ponoszonych na ich rzecz inwestycji.

5. Różnorodność to tylko politycznie poprawny zwrot dla akcji afirmatywnych.

Ponadto na niejednoznaczność korzyści i efektywności zróżnicowanych zespołów wskazują Elizabeth Mannix i Margaret Ann Neale (2005, s. 31-55), David Harrison i inni (1998, s. 96-107), Fred Luthans, Jonathan Doh (2009, s. 174) czy polscy badacze Krzysztof Łobos i Daniel Puciato (212, s. 151-152).

Choć w ramach krytycznego nurtu badań nad zarządzaniem różnorodnością w organizacji co jakiś czas wyłania się kwestia kultury i/lub klimatu organizacyjnego, to jednak problemy te nie są podejmowane, co tylko potwierdza istotę zagadnienia i konieczność kontynuowania badań w tym zakresie (Gross-Gołacka, 2018, s. 94).

Zwolennicy nurtu krytycznego badanej koncepcji poruszają również kwestię kontekstu społecznego. Wspomniani już badacze Alison Konrad, Pushkala Prasad i Judith Pringle (2006, s. 1-22) wskazują, że kontekst makro ma bezpośredni wpływ na to, które zagadnienia związane $\mathrm{z}$ różnorodnością stają się widoczne. Podkreślają, że kluczowe aspekty kontekstu dla zrozumienia różnorodności obejmują historię i opresyjne działania ukierunkowane na różne grupy oraz prawodawstwo dotyczące dostępu do wykształcenia, pracy i opieki zdrowotnej, praw człowieka, położenia społecznego różnorodnych grup i które ulegały zmianom w wyniku aktywizmu międzynarodowego i na poziomie lokalnym. Według tego podejścia implikacje postkolonializmu i postimperializmu dotyczące inności mają istotny wpływ na postrzeganie różnorodności w organizacji. Dyskursy tworzone są zarówno w obrębie organizacji, jak i przez nie. Wielokulturowe społeczeństwa, jak te w USA, 
Kanadzie, Wielkiej Brytanii i Australii, mają tendencję do wykształcenia większej tolerancji i doceniania różnic w porównaniu do społeczeństw takich jak te w krajach Europy Środkowo-Wschodniej czy krajach skandynawskich. W tym duchu pojawia się głos krytyczny wobec istotności anglosaskiego rozumienia zarządzania różnorodnością i możliwości jego zastosowania w innych krajach. W odniesieniu do Polski taki głos krytyczny wyrażali Monika Kostera i Łukasz Sułkowski.

Zasadniczo uniwersalizm w odniesieniu do paradygmatów w naukach o zarządzaniu jest ograniczony na skutek dużej różnorodności świata (otoczenia), odmiennych poziomów rozwoju gospodarczego, technicznego i cywilizacyjnego czy występowania różnic kulturowych. Paradygmat oddający uogólnioną rzeczywistość w zakresie zarządzania w jednym kraju, regionie może być nieadekwatny do sytuacji w innym państwie czy regionie. Także naukowcy Ryszard Bartkowiak i Piotr Wachowiak (2016, s. 13) wskazują na konieczność stworzenia paradygmatów narodowych - dla Azji Wschodniej, Afryki Subsaharyjskiej, a także Europy Środkowej. Dotyczy to zwłaszcza nauk o zarządzaniu, w tym koncepcji zarządzania różnorodnością, w których coraz silniej kładzie się nacisk na historyczne i kulturowe aspekty kierowania procesami gospodarczymi. Z założenia nauki społeczne uwikłane są kontekst kulturowy i społeczny (Gross-Gołacka, 2018, s. 95).

Jako że nurt krytyczny jest refleksją poszukującą powiązań między funkcjonującą wiedzą o zarządzaniu a kulturowymi, społecznymi czy politycznymi uwarunkowaniami zarządzania w organizacji, na osobną uwagę zasługuje kwestia racjonalizowania obecności kwestii genderowych w tym dyskursie. Łukasz Sułkowski (2014, s. 98) wskazuje, że analizy nie tylko dotyczą tego, jak płeć determinuje życie jednostek jako uczestników organizacji i procesów zarządzania, ale również pozwalają spojrzeć na organizacje i procesy zarządzania z szerszej perspektywy: jako na wyrazicieli i nośniki określonych wartości i zasad aktywnych w konstruowaniu zrozumienia, postrzegania i doświadczenia męskości i kobiecości. W ostatnich 20 latach widoczne są dwie wyraźne tendencje $\mathrm{w}$ analizowanym zagadnieniu. $\mathrm{Z}$ jednej strony kwestie genderowe traktowane są jako element zarządzania różnorodnością (Cox, 1994; Thomas \& Ely, 1996, s. 79-90) i postrzegane, głównie przez praktyków, w kategoriach opłacanej strategii (Making Change: Creating a Business Case 
for Diversity, 2002; The Bottom Line..., 2004; Women Matter..., 2007; Why diversity matters..., 2015), z drugiej zaś umniejsza się ich znaczenie, traktując je jako problem, który przestał być istotny (Sułkowski \& Zawadzki, 2014, s. 97). Ograniczona w niniejszym artykule dyskusja dotycząca zarządzania różnorodnością wraz z powiązanymi teoriami wynika z ograniczonego miejsca w pracy. Temat ten zasługuje na odrębne analizy - istnieje potrzeba kontynuacji badań w tym zakresie.

\section{Podsumowanie}

Badaczy z nurtu krytycznego zasadniczo łączy przekonanie, że w badaniach i teoriach z głównego nurtu koncepcji zarządzania różnorodnością pomijane są niezwykle istotne zagadnienia. Badacze ci wskazują na zjawiska nierówności, opresji i dominacji czy eksploatacji. Raczej nie mamy do czynienia z zagorzałymi przeciwnikami tej koncepcji, a podejmowany jest dialog pomiędzy zwolennikami różnych podejść. Pogłębione analizy paradygmatu krytycznego pozwalają na rozważania nad koncepcją zarządzania różnorodnością w kontekście innych subdyscyplin wchodzących w skład nauk o zarządzaniu, co tylko potwierdza interdyscyplinarność tej koncepcji i silny związek z innymi dyscyplinami naukowymi, chociażby z ekonomią, psychologią czy filozofią i socjologią, a nawet biologią. Kwestia uwzględniania tej złożoności to niejedyny postulat (Gross-Gołacka, 2018, s. 96). Tymczasem - co wynika $\mathrm{z}$ analizy literatury przedmiotu i jest zgodne ze zdaniem Autorki - istotne jest to, że zmienne znaczenie przypisywane różnorodności w organizacji należy zawsze rozważać w zależności od kontekstu i otoczenia, w jakim ona funkcjonuje. Ponadto, znaczenia określonych cech demograficznych - jak płeć, wiek, pochodzenie etniczne, rasa i inne - nie należy brać za oczywiste i stałe. Zarówno znaczenie tych cech, jak i istotność wcale nie są stałe - są uwikłane w kontekst społeczny i kulturowy.

Reasumując, nurt krytyczny w naukach o zarządzaniu daje duże możliwości badawcze i dużą przestrzeń dla autorefleksji. Jednocześnie jest podejściem, które umożliwia odejście od znaczącej roli dominacji inżynierii społecznej z jego instrumentalnym podejściem do człowieka w organizacji na rzecz zachowania godności i podmiotowości ludzkiej w organizacji. Ale również bywa dość kontrowersyjny, ponieważ założenia tworzące jego oś mają 
charakter ideologiczny. W świetle powyższych rozważań warto wspomnieć, że oczywiste jest, że na rozwój nauk o zarządzaniu mają wpływy ideologie.

Niezależnie od przyjętej we współczesnym społeczeństwie definicji zarządzania różnorodnością nie sposób traktować jej jako jedynie zbioru narzędzi służących rozwiązywaniu problemów związanych z zarządzaniem zasobami ludzkimi. Pamiętać należy, że ani podejście do zróżnicowanych zasobów ludzkich w organizacji, ani inspirowane nim działania nie występują w próżni kulturowo-społecznej, ale wpisane są w konkretny kontekst i w tym kontekście powinny być analizowane i oceniane.

\section{Literatura}

Alvesson, M., Willmott, H. (1992). Critical Management Studies, London: Sage. ISBN 9780803984547.

Bartkowiak, R., Wachowiak, P. (red.). (2016). Nowe paradygmaty w naukach ekonomicznych, Warszawa: Oficyna Wydawnicza Szkoły Głównej Handlowej. ISBN 9788380300668.

Braverman, H. (1974). Labour and Monopoly Capital: The Degradation of Work in the Twentieth Century, New York: Monthly Review Press. ISBN 9780853459408.

Carter, E., Kepner, E., Shaw, M., Woodson, W.B. (1982). The effective management of diversity. Society for the Advancement of Management, „Advanced Management Journal" nr 47, s. 49-53. ISSN 0036-0805.

Cox, T. (1994). Cultural Diversity in Organizations: Theory, Research and Practice, San Francisco: Berrett-Koehler Publisher Inc. ISBN 9781881052432.

Dick, P., Cassell, C. (2002). Barriers to managing diversity in a Great Britain, constabulary: the role of discourse, „Journal of Management Studies” t. 39(7). ISSN 1467-6486.

Duberley, P., Johnson, J. (2003). Understanding Management Research: An Introduction to Epistemology, London: Sage. ISBN 9780761969181.

Foldy, E.G. (2002). Managing diversity: identity and power in organizations. W: I. Aaltio, A.J. Mills (red.), Gender, Identity and Culture of Organizations, London: Routledge, s. 92-112. ISBN 978-0415270014.

Griggs, L.B. (1995). Valuing diversity: Where from ...where to?. W: L.B. Griggs, L.L. Louw (red.), Valuing diversity: New tools for a new reality, New York: McGraw-Hill, s. 1-14. ISBN 978-0070247789. 
Gross-Gołacka, E. (2018). Zarządzanie różnorodnością. W kierunku zróżnicowanych zasobów ludzkich, Warszawa: Difin. ISBN 9788380855229.

Gross-Gołacka, E. (2013). Zarządzanie różnorodnościa jako strategia firmy, „Przedsiębiorczość i Zarządzanie" t. 14, nr 12, cz. 2, s. 313-326.

Harrison, D.A., Price, K.H., Bell, M.P. (1998). Beyond relational demography: Time and the effects of surface- and deep-level diversity on work group cohesion, „Academy of Management Journal" nr 41, s. 96-107. ISSN 0001-4273.

Heran, J., Collinson, D. (2006). Men, masculinities and Workplace Diversity/Diversion: power, Intersections and Contradictions. W: A.M. Konrad, P. Prasad, J.K. Pringle (red.), Handbook of workplace diversity, London: Sage, s. 299-322. ISBN 9780761944225.

Konrad, A.M., Prasad, P., Pringle, J.K. (1997). Managing the Organizational Melting Pot. Dilemmas of Workplace Diversity, London: Sage. ISBN 9780803974111.

Konrad, A.M., Prasad, P., Pringle, J.K. (2006). Examining the Contours of workplace Diversity: Concepts, Contexts and Challenges. W: A.M. Konrad, P. Prasad, J.K. Pringle (red.), Handbook of workplace diversity, London: Sage, s. 1-22. ISBN 9780761944225.

Konrad, A.M., Prasad, P., Pringle, J.K. (red.). (2006). Handbook of Workplace Diversity, London: Sage. ISBN 9780761944225.

Kostera, M. (1996). Postmodernizm w zarzadzaniu, Warszawa: Polskie Wydawnictwo Ekonomiczne. ISBN 8320810175.

Koźmiński, A.K., Piotrowski, W. (red.). (2010). Zarzadzanie. Teoria i praktyka, Warszawa: PWN. ISBN 9788301164416.

Krajewski, P. (2017). Prawo człowieka do środowiska jako potrzeba wielowymiarowych zależności i relacji człowieka z otoczeniem. W: E. Ura, B. Sitek, T. Graca (red.), Potrzeby jako współczesny determinant treści praw człowieka. Józefów: Wydawnictwo Wyższej Szkoły Gospodarki Euroregionalnej im. Alcide De Gasperi. ISBN 9788362753864 .

Litvin, D. (1997). The Discourse of Diversity: From Biology to Management, „Organization" nr 4(2), s. 187-209. ISSN 1350-5084.

Litvin, D. (2006). Diversity. Making Space for a Better Case. W: A.M. Konrad, P. Prasad, J.K. Pringle (red.), Handbook of workplace diversity, London: Sage, s. 75-94. ISBN 9780761944225.

Łobos, K., Puciato, D. (2012). Dekalog wspótczesnego zarządzania. Najnowsze nurty, koncepcje, metody, Warszawa: Difin. ISBN 9788376418735. 
Loden, M., Rosener, J.B. (1991). Workforce America! Managing employee diversity as a vital resource, Homewood: Business One Irwin. ISBN 9781556233869.

Lorbecki, A., Jack, G. (2000). Critical Turns in the Evolution of Diversity management, „British Journal of Management” tom 11(3), s. 17-31. ISSN 1045-3172.

Luthans, F., Doh, J.P. (2009). International Management. Culture, Strategy and Behaviour, New York: McGraw-Hill/Irwin. ISBN 978-9814577298.

Making Change: Creating a Business Case for Diversity (2002), New York, San Jose, Toronto: Catalyst.

Mannix, E., Neale, M.A. (2005). Why difference make a difference?, „Psychological Science in the Public Interest" nr 6, s. 31-55. ISSN 1529-1006.

Maslow, A. (1943). A Theory of Human Motivation, „Psychological Review” nr 50(4). ISSN 0033-295X.

McGregor, D. (1960). The Human Side of Enterprise, New York: McGraw-Hill.

Münsterberger, H. (1913). Psychology and Industrial Efficiency, Boston: Houghton Mifflin.

Özbilgin, M.F., Tatli, A. (2008). Global Diversity Management: An Evidence-based Approach, Basingstoke: Palgrave Macmillan. ISBN 9781403996107.

Özbilgin, M.F., Tatli, A. (2011). Mapping out the field of equality and diversity: rice of individualism and voluntarism, „Human Relation” t. 64, nr 9, s. 1229-1253. ISSN 0018-7267.

Roethlisberger, F.J., Dickson, W. (1939). Management and the Worker, Cambridge: Harvard University Press. ISBN 978-0674546769.

Sitek, M. (2016a). Respecting the human rights - the rights of immigrants. Between needs and capabilities of the countries hosting the immigrants. W: M. Sitek, S. Stadniczeńko (red.), The rights of migrants between the needs and capabilities of the state and the international community. Józefów: Wydawnictwo Wyższej Szkoły Gospodarki Euroregionalnej im. Alcide De Gasperi. ISBN 9788362753734.

Sitek, M. (2016). Prawa (potrzeby) człowieka w ponowoczesności, Warszawa: C.H. Beck. ISBN 9788325589226.

Stockdale, M.S., Crosby, F.J. (2004). The psychology and management of Workforce diversity, San Francisco: Blackwell Publishing. ISBN 9781405100960.

Sułkowski, Ł, Zawadzki, M. (red.). (2014). Krytyczny nurt zarzadzania, Warszawa: Difin. ISBN 9788379303977. 
Sułkowski, Ł. (2012). Epistemologia i metodologia zarzadzania, Warszawa: Polskie Wydawnictwo Ekonomiczne. ISBN 9788320820270.

Sułkowski, Ł. (2014). Paradygmat krytyczny organizacji i zarzadzania. W: Ł. Sułkowski, M. Zawadzki (red.), Krytyczny nurt zarządzania, Warszawa: Difin. ISBN 9788379303977.

Szejniuk, A. (2015). Kapitał Ludzki jako wyznacznik sukcesu organizacji, „Journal of Modern Science" nr 3/26, s. 47-60. ISSN 1734-2031.

Thomas, D.A., Ely, R.J. (1996). Managing Differences Matter: A new Paradigm for Managing Diversity, „Harvard Business Review” nr 74, s. 79-90. ISSN 0017-8012.

Waszczak, S. (2009). Postawy wobec różnorodności - uwarunkowania, próba typologii, implikacje. W: M. Juchnowicz (red.), Kulturowe uwarunkowania zarządzania kapitałem ludzkim, Kraków: Wolters Kluwer. ISBN 9788375266818.

Wrench, J. (2005). Diversity management can be bad for you, „Race \& Class” t. 46(3), Institute of Race Relation. ISSN 0306-3968.

\section{Źródła internetowe}

The Bottom Line: Connecting Corporate Performance and Gender Diversity (2004), Catalyst, http://www.catalyst.org/system/files/The_Bottom_Line_Connecting Corporate_Performance_and_Gender_Diversity.pdf (dostęp: 22.10.2016).

Diversity matters (2015), McKinsey \& Company, https://www.mckinsey.com/ / media/mckinsey/business\%20functions/organization/our\%20insights/ why\%20diversity\%20matters/diversity\%20matters.ashx (dostęp: 22.10.2016).

Women Matter: A Corporate Performance Driver (2007), McKinsey \& Company, https://www.mckinsey.com/ /media/mckinsey/dotcom/client_service/Organization/PDFs/Women_matter_oct2007_english.ashx (dostęp: 22.10.2016). 